\title{
Impacts of increased tourism on polar environment - case studies from Svalbard and Iceland
}

\author{
Jan Kavan $^{1 *}$, Veronika Anděrová ${ }^{2}$ \\ ${ }^{1}$ Polar-Geo-Lab, Department of Geography, Faculty of Science, Masaryk University, \\ Kotlářská 2, 611 37, Brno, Czech Republic \\ ${ }^{2}$ Department of Zoology, Faculty of Science, University of South Bohemia, Branišovská \\ 1760, 37005, České Budějovice, Czech Republic
}

\begin{abstract}
The increasing number of visitors in polar regions and demand for outdoor extreme activities create a pressure on local fragile ecosystems. Two examples of mechanical disturbances of the glacier forefields are presented in this study to demonstrate the impacts of different frequencies of visits on the local environment. Foxfonna study site experience only minor disturbances in comparison with the Langjökull study site on Iceland. This is due to the number of tourists visiting the two localities and also the means of transportation used for reaching the ice caps. It is likely that with still ongoing increase of number of tourists coming to these localities, the anthropogenic pressure will continue to grow. The combination of human pressure and ongoing climate change can have irreversible effects on sensitive local environment especially in places easily accessible for tourists.
\end{abstract}

Key words: environment, glaciers, human pressure, Svalbard, Iceland

DOI: $10.5817 / C P R 2020-1-6$

\section{Introduction}

During the last decades, polar regions experienced high increase of visitors and related tourism activities. The quest for exploring the polar wilderness pushes the tourist agencies to go further in offering diverse outdoor activities and continue to explore new territories. These activities are necessary to meet the tourists' demands. With increasing number of arriving tourists and rise in the offer of local tourist agencies, negative impacts on local environment start to occur (e.g. Tverijonaite et al. 2018, Runge et al. 2020). The human pressure together with the effects of climate change can have significant impacts on animal species, vegetation and the landscape as a whole. For the moment, most of the studies dealing with tourism in the Arctic take into account the possible effect of climate change on tourism (e.g. Hewer and

Received October 4, 2019, accepted May 13, 2020.

*Corresponding author: J. Kavan <jan.kavan.cb@gmail.com>

Acknowledgements: The field work was carried out thanks to the financial support of the InterAct project "GlacSedRun" n. 387 and "Cool Science" project under the funding of Norway grants "EHP-CZ-ICP-1-003". The research was financially supported by the project LM2015078 and the projects of Masaryk University MUNI/A/1576/2018 and ARCTOS MU (MUNI/G/1540/2019). Thanks also belongs to Zdeněk Stachoň for postprocessing of the dGPS measurements. 
Gough 2018, Wang and Zhou 2019, Schrot et al. 2019). Less studied is the opposite, i.e. the effect of tourism on local environment which, however, often amplifies the negative effect of climate change. Some examples are represented in e.g. Wang et al. (2019) or Czortek et al. (2018). One of the recent impacts on local environment is certainly the use of off-road or all-terrain vehicles for access to the distant localities (Hinkel et al. 2017). The importance of transportation and its effect on reshaping the local surface was identified long time ago (e.g. Abele et al. 1984). In the 80ies, only local inhabitants and local industrial companies were moving around the settlements. This has, however, changed in the last decade and tourism related transportation became the leading sector using offroad vehicles.

The number of tourists has been constantly increasing in Svalbard. This trend is well illustrated on the Fig. 1A, where number of incoming passengers to the Longyearbyen airport is plotted. The number almost doubled in last decade from 53000 in 2009 to 90000 in 2018 ([1] - SSB 2019). The same trend is obvious from the number of guests' nights in local hotels, where increase from less than 50000 in late 90ies to more than 150000 in 2015 is apparent (Eeg-Henriksen and Sjømæling 2016).

Similar trend could be observed in case of Iceland (Fig. 1B, C), where detailed statistics on arriving foreign passengers to Keflavik airport is available since 50ies. The increasing number of arriving tourists is even more pronounced in comparison to Svalbard. In 2009 the number of incoming foreign passengers was 494000 whereas in 2018 the number has increased up to 2344000 . Such enormous increase in number of tourists was accompanied by consequent increase in tourist activities, travel agencies offers and increase in accommodation capacities. The importance of increasing tourism on the state of the local environment was obviously recognized in Iceland as well, Ólafsdóttir and Runnström (2013) examined the state of hiking trails and its impact on enhanced erosion in Icelandic highlands for example. The climatic conditions of Iceland, especially strong winds and precipitation lead to intensive wind and water erosion (Arnalds et al. 2012), that might enhance the negative effects of increased tourism.

The objective of the study is to describe the physical damage on local environment in means of terrain alterations caused by heavy transportation directly related to tourism activities. Such damage is described with use of UAV photography and publicly available aerial photos together with direct land-based observation.

\section{Study sites}

Two study sites of glacier forefields were investigated during July and August 2019. Their positions are marked in Fig. 2. Svalbard is located in High Arctic environment with rather low precipitation and long-term average temperatures in nearby Adventdalen reaching approximately $-7^{\circ} \mathrm{C}$ (Nordli et al. 2014). On the other hand,

Iceland can be considered as subarctic environment with higher temperatures and especially higher precipitation. However, both localities are rather similar with respect to their landscape context. Both are located in the vicinity of the ice caps, both localities are experiencing rather important glacier retreat in last decades. 


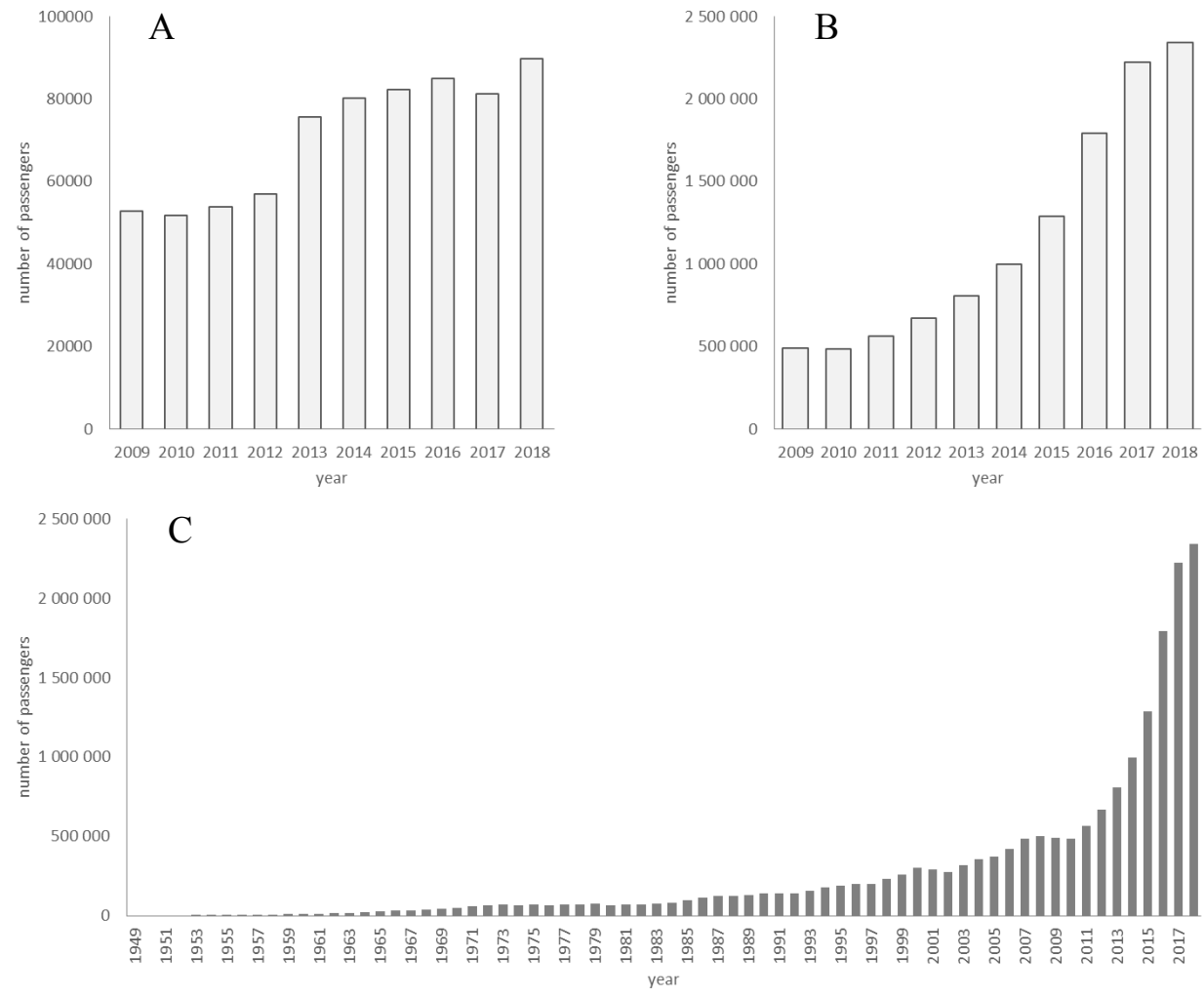

Fig. 1. Number of incoming passengers to Svalbard (A, ([1] - SSB 2019) and number of arriving foreign passengers to Keflavik airport (Iceland) (B) for 2009-2018 with a long-term trend for Iceland 1949-2018 (C, Ásgeirsdóttir and Karlsson 2016).

\section{Foxfonna, Svalbard}

The study site is located about $2 \mathrm{~km}$ in front of Foxfonna, one of the most easily accessible ice caps on Svalbard, not far away from the archipelagos' capital, Longyearbyen. The site is frequently visited by organised groups of tourists, usually with use of off-road vehicles to reach the ice cap summit. Even though the Governor of Svalbard office is rather strict regarding the environmental protection, substantial damage of ground surface is visible. The study site itself is located in the northern forefield about $2 \mathrm{~km}$ off the ice cap edge on the relatively flat plateau where ice wedged polygons are very well developed. The Fox- fonna site represents a remote locality accessible only for few visitors especially because of the need to walk for relatively long distance and be in a good physical shape. The local tourist agencies advertise the summer guided trip as moderate to difficult with necessity to walk approximately $11 \mathrm{~km}$ in rugged terrain and limit the minimum age of 12 years to attend the trip. The winter trips are however more accessible due to the use of snowmobiles, allterrain vehicles or dog sledges. It is therefore especially the winter activities causing the terrain alterations. 

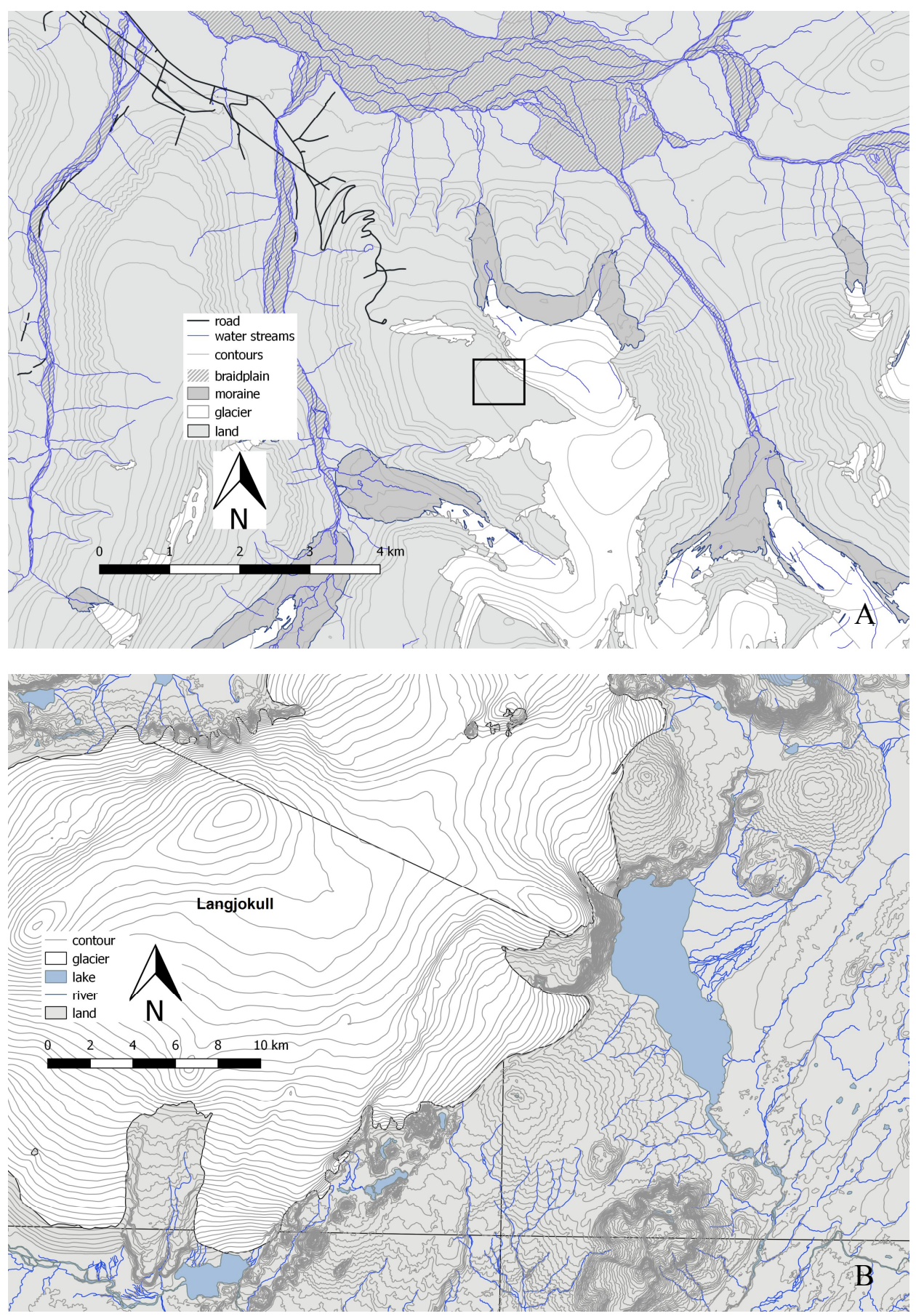

Fig. 2. Locations of the two study sites with close-up of Foxfonna site in Svalbard (A) and Langjökull in Iceland (B). 


\section{Langjökull, Iceland}

Langjökull is the second largest Icelandic ice cap $\left(953 \mathrm{~km}^{2}\right)$ located not far from the capital, Reykjavík. This position makes it a perfect touristic spot. Number of tourists reaching Langjökull is much higher in comparison to Foxfonna study site in Svalbard. The Foxfonna site is visited by maximum of tens persons per day, whereas Langökull can be reached by hundreds or even thousands per day. This corresponds also to the infrastructure which has been recently developed. On contrary to still rather untouched environment of Foxfonna, Langjökull is easily accessible by car. Organised groups are then transported on the edge of the ice cap with off road buses and further on the ice cap summit with snow scooters (Fig. 3).

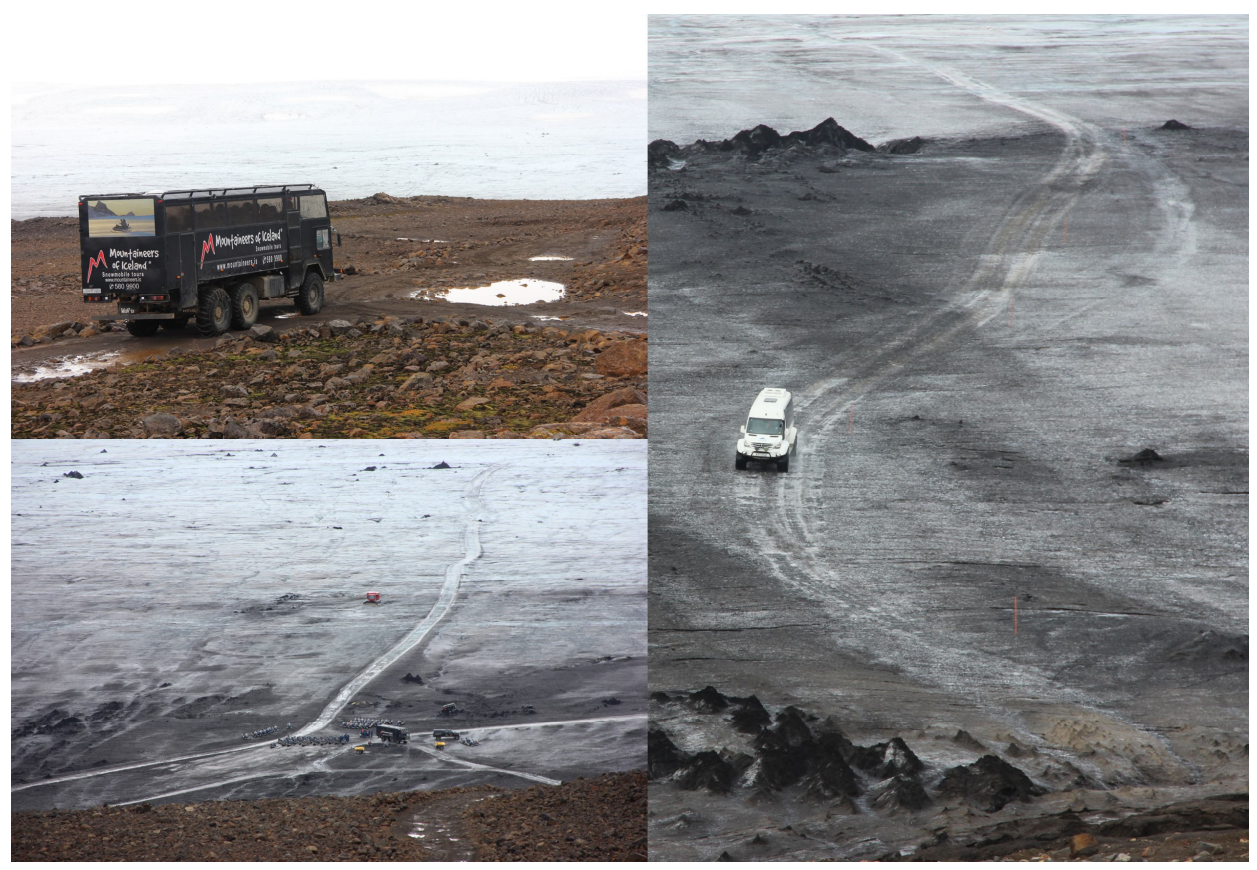

Fig. 3. Transportation means used for moving to the Langjökull glacier and on its surface.

\section{Material and Methods}

Unmanned aerial vehicle (UAV) was used for mapping of the Foxfonna study site. The Yuneec MantisQ drone has recorded 30 minutes $4 \mathrm{k}$ video from which 76 selected photographs were used. Structure from Motion (SfM) technique was used for constructing orthophoto and digital elevation model (DEM). Orthophoto and DEM was processed in Photoscan Agisoft software. 4 reference points were recorded in the field with Trimble dGPS device for the period of 120 seconds for each point. Horizontal precision of the dGPS reference points was in average $0.175 \mathrm{~m}$ and vertical precision $0.35 \mathrm{~m}$ after the postprocessing. The spatial error of the reference points after alignment within the Agisoft environment was $0.82 \mathrm{~m}$. The resulting orthophoto was exported with $0.03 \mathrm{~m}$ resolution and DEM in $0.1 \mathrm{~m}$ resolution. 
Publicly available aerial photos ([2]) and direct land-based observation were used to illustrate the impact of transportation on the terrain at the Langjökull study site. The old aerial photo([3] - National Land Survey of Iceland database 2019) from August

\section{Results and Discussion}

Substantial terrain alterations were found in both studied localities. The disturbances found at Foxfonna site were considerably smaller in comparison with the Langjökull site. This is no surprise with regard to the much lower number of tourists visiting Svalbard and the locality itself.

The Foxfonna study site and the level of disturbance is presented in Fig. 4. The tracks from the off-road vehicles are well visible crossing the high plateau with welldeveloped sorted polygons. The high water content in the active layer leading to rather soft and vulnerable surface contributed to relatively deep impacts of just few vehicles crossing the area. Even though the tracks are clearly visible on the orthophoto, the spatial impact on the surface is not detectable on the DEM with $0.1 \mathrm{~m}$ resolution. On the other hand, such tracks persist for several decades in the bare soil surface ecosystem of the high elevated plateau. These tracks are visible for several decades even on the vegetated tundra surface, where the potential to recover is much higher, which could be shown on examples of offroad operations in the vicinity of polar stations or nearby the old Russian settlements on Svalbard.

In case of the Langjökull study site, the imprints of the transportation are more persistent, especially because of construction of transportation and logistics infrastructure directly at the site and relatively high frequency of visits. $12.9-17.7 \%$ of tourists visiting Iceland has paid for glacier/snow- $14^{\text {th }} 1986$ was used for comparison of the study site before construction of the transportation infrastructure (photo ID J-7886). The recent aerial photograph was taken in August 2018.

mobile guided tours between 2011 and 2016 (Ásgeirsdóttir and Karlsson 2016), which means approximately 300000 visitors of Icelandic glaciers. Considering that Langjökull is the glacier closest to the country's capital, where large part of the visitors is going and have two principal access sites, it can be estimated that several tens of thousands of visitros per year can use this infrastructure. As shown on Fig. 5, the site near Langjökull glacier haven't been accessible by car in late 80 ies and the transport facilities have been constructed only in late 90ies, when the local tourist agency started to organize the tours on the glacier surface. Even though the agency stated its carbon dioxide neutral footprint on environment through supporting reforestation programmes, its impact on the local glacier forefield is inevitable. The footprint on the landscape is obvious as well as the tracks on glacier surface. The question of chemical contamination of the glacier itself through the emissions from snowmobiles and other vehicles arises apart the mechanical disturbances. The important impact of snowmobile emissions on Svalbard environment was reported e.g. by Reimann et al. (2009) or Aamaas et al. (2011). Apart the direct emissions ranging from $2.5 \mathrm{~g} / \mathrm{km}$ to $69 \mathrm{~g} / \mathrm{km}$ depending on type of engine, Reimann et al. (2009) also reported that large part of the fuel leaves the engine unburned and contaminates the surface directly with the fuel. 


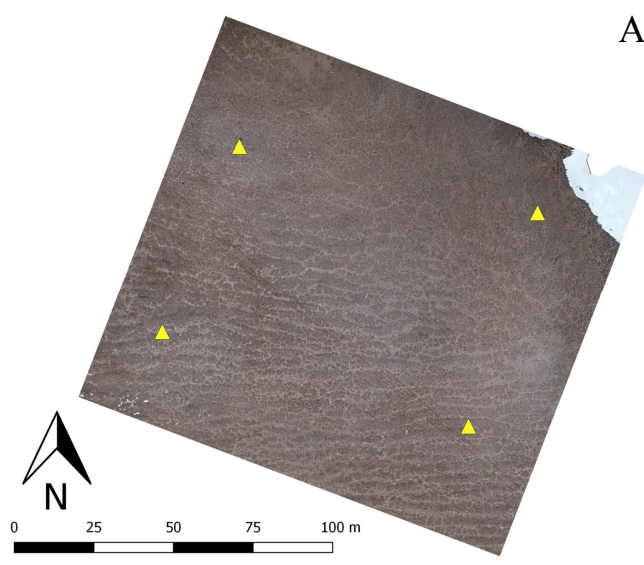

A
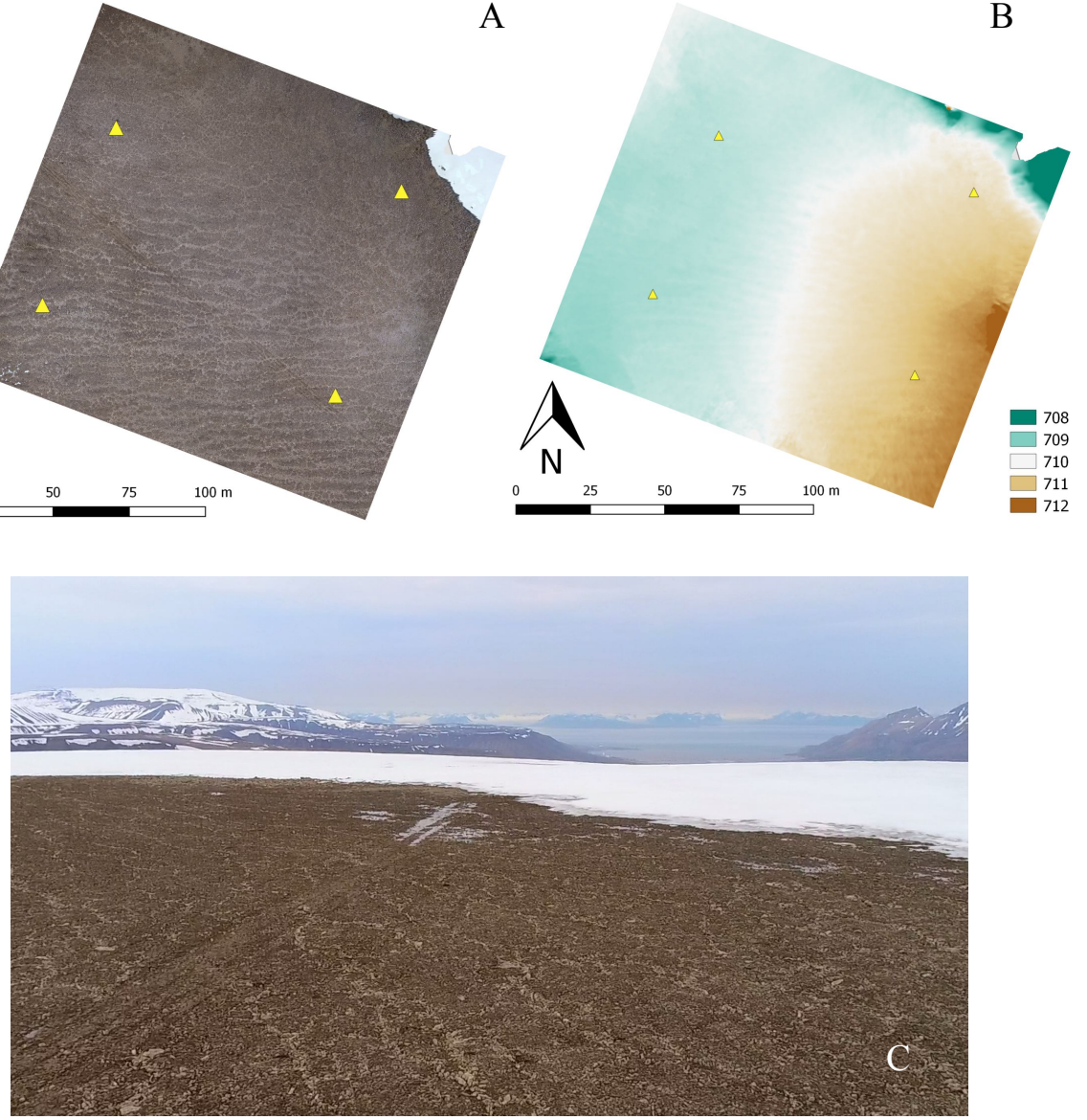

Fig. 4. Orthophotograph of Foxfonna study site (A) and the DEM produced with SfM technique (B) with an oblique close up focused on disturbed ice wedged polygons on the high elevated plateau and Adventfjord with Longyearbyen, the Svalbards' capital, in the background (C).

Burning huge amount of fossil fuels (the average consumption of a snowmobile ranges from 13.1 to $18.1 \mathrm{l} / \mathrm{km}$ according to the survey of Reimann et al. 2011) directly on the glacier surface might contribute to elevated levels of certain chemical compounds (i.e. aromatic hydrocarbons) but also increase the glacier albedo by deposition of dust particles directly related to fossil fuel burning.

The effects of transportation on surface layer of tundra soils was found to be important even several decades ago (see e.g. Abele et al. 1984, Buchkina et al. 1998). The artificial deepening of certain zones due to deep trails of the vehicles can change the surface hydrology of the flat Foxfonna study site. This may have significant effect on reshaping the ice wedge polygons as described in similar conditions by Hinkel et al. (2017). Use of offroad vehicles has been identified to have extensive impacts on the landscape also by Eisner et al. (2008) in Alaska. Landscape degradation directly related to tourism activities was identified by several studies from polar or high-mountainous regions (e.g. Hawes et al. 2006, Tomczyk and Ewertowski 2011). 

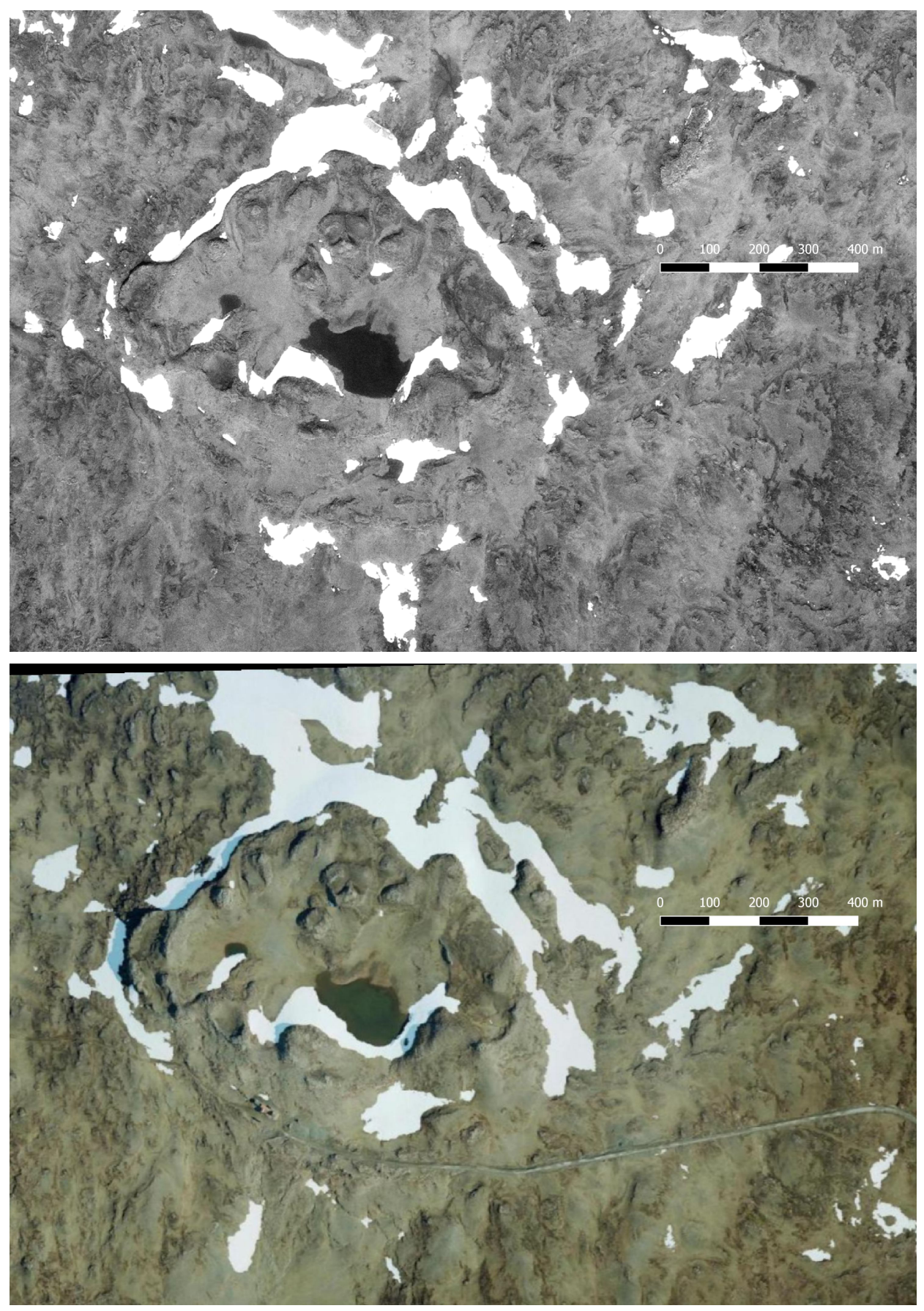

Fig. 5. Comparison of 1986 and 2018 aerial photos from the Langjökull study site with visible road coming to the study site from east and the tourism infrastructure close to the lake constructed in 90ies; the Langjökull ice cap is located approximately $1 \mathrm{~km}$ to the west from the site (modified from photos at [3] - National Land Survey of Iceland database and [2]) . 


\section{Conclusions}

It is obvious that with massive increase of tourism in polar regions, there are inevitable consequences for local environment. These impacts are often concentrated in few areas, that are widely used by groups of tourists organized by local travel agencies. It is the case of both studied localities - Foxfonna in Svalbard and Langjökull in Iceland. In correspondence with much higher number of tourists arriving to Iceland, the effects on terrain disturbances are more pronounced in the Langjökull site. New transportation infrastructure has been developed in last two decades especially for the purpose of facilitating access on the ice cap for tourists. The infrastructure and number of vehicles have direct impact on the forefield of the ice cap but also on the glacier surface itself. The negative effects of off-road transportation are visible in case of Foxfonna site as well. These disturbances are, however, present in much smaller scale and are probably a result of individual breaking of environmental law restricting in general off-road activities.

Ásgeirsdóttir and Karlsson (2016) demonstrated that $12.9-17.7 \%$ of tourists visiting Iceland has paid for glacier/snowmobile guided tours between 2011 and 2016 . This percentage suggests several tens of thousands of visitors per year in the Langjökull locality. The high concentration of tourists to the most famous Icelandic natural sites have been recognized as the biggest problem for natural conservation and sustainable development of tourist business by the authorities. Number of actions to support spatial diversification of visits have been therefore employed from 2010 (Øian et al. 2018). The high tourist pressure on nature has been also identified as the biggest problem concerning tourism in the survey among the local Icelandic population (Óladóttir 2019). Svalbard is obviously less visited (see Fig. 1) and proportionally low number of visits can be expected at the study site - especially taking into account the relative difficulty of accessing the locality. However, the rising trend in visits persisting for several consecutive years suggests that the pressure is about to rise.

The Arctic tourism as a special branch of tourism market has emerged during the last three decades (Viken 2011) and both regions are a good example of tourismoriented economies. As shown by Saarinen and Varnajot (2019), the demand for "Arctic" experience is still high. On one hand, Øian et al. (2018) identified the preserved nature and experience of solitude as an important reason for visiting the Arctic. On the other hand, too many tourists concentrated on touristic sites can damage this impression and reduce the demand for visiting the Arctic countries in general. There is a challenge for the future to balance the sustainable development and nature conservation of the Arctic environment with the high demand and increasing number of tourists, that may lead to its damage.

\section{References}

Aamaas, B., Boggild, C. E., Storda, F., Berntsen, T., Holmen, K. and Ström, J. (2011): Elemental carbon deposition to Svalbard snow from Norwegian settlements and long-range transport. Tellus B: Chemical and Physical Meteorology, 63: 340-351.

Abele, G., Brown, J. and Brewer, M. C. (1984): Long-term effects of off-road vehicle traffic on tundra terrain. Journal of Terramechanics, 21: 283-294.

Arnalds, Ó., GísladótTIR, F. Ó. and ORRADÓTTIR, B. (2012): Determination of aeolian transport rates of volcanic soils in Iceland. Geomorphology, 167-168: 4-12. 
ÁsgeirsdótTiR, T., KARLSSON, T. (2016): International visitors in Iceland - summer 2016. Icelandic Tourist Board. $405 \mathrm{p}$.

Buchkina, N. P., ZuYev, V. S. and Balashov, E. V. (1998): Effects of tracked vehicles on the morphological and physical properties of tundra soils. Soil and Tillage Research, 48(4): $317-$ 324.

Czortek, P., Delimat, A., Dyderski, M. K., Zieba, A., Jagodzinski, A. M. and Jaroszewicz, B. (2018): Climate change, tourism and historical grazing influence the distribution of Carex lachenalia Schkuhr - A rare arctic-alpine species in the Tatra Mts. Science of the Total Environment, 618: 1628-1637.

Eeg-Henriksen, F., Sjømæling E. (2016): This is Svalbard 2016. Statistics Norway, 28 p.

Eisner, W. R., Hinkel, K. M., Jones, B. M. and Cuomo, C. J. (2008): Using indigenous knowledge to assess environmental impacts of overland travel routes, Arctic Coastal Plain of Alaska. In: D. L. Kane, K. M. Hinkel (eds.): Ninth International Conference on Permafrost, Institute of Northern Engineering, University of Alaska, Fairbanks, AK, pp. 415-420.

HAwES, M., CANDY, S. and DixON, G. (2006): A method for surveying the condition of extensive walking track systems. Landscape and Urban Planning, 78: 275-287.

Hewer, M. J., Gough, W. A. (2018): Thirty years of assessing the impacts of climate change on outdoor recreation and tourism in Canada. Tourism Management Perspectives, 26: 179-192.

HINKEL, K. M., EISNER, W. R. and KIM, C. J. (2017): Detection of tundra trail damage near Barrow, Alaska using remote imagery. Geomorphology, 293: 360-367.

Nordli, O., Przybylak, R., Ogilvie, A. E. J. and Isaksen, K. (2014): Long-term temperature trends and variability on Spitsbergen: the extended Svalbard Airport temperature series, 18982012. Polar Research, 33: 21349.

Øian, H., Fredman, P., Sandell, K., Słepórsdóttir, A.D., Tyrväinen, L. and Søndergaard JENSEN F. (2018): Tourism, nature and sustainability - A review of policy instruments in the Nordic countries. TemaNord 2018: 534, 103 p.

ÓlADÓTTIR, O. T. (2019): Tourism in Iceland in Figures. Icelandic Tourist Board, 28 p.

Reimann, S., Kallenborn, R. and Schmidbauer, N. (2009): Severe aromatic hydrocarbon pollution in the arctic town of Longyearbyen (Svalbard) cause by snowmobile emissions. Environmental Science and Technology, 43: 4791-4795.

Runge, C. A., Daigle, R. M. and Hausner, V. H. (2020): Quantifying tourism booms and the increasing footprint in the Arctic with social media data. PLOS ONE, 15(1): e0227189.

SAARINEn, J., VARnAJot, A. (2019): The Arctic in tourism: complementing and contesting perspectives on tourism in the Arctic. Polar Geography, 42: 109-124.

Schrot, O. G., Christensen, J. H. and Formayer, H. (2019): Greenland winter tourism in a changing climate. Journal of Outdoor Recreation and Tourism, 27: 100224 .

TOMCZYK, A. M., EwERTOwski, M. (2011): Degradation of recreational trails, Gorce National Park, Poland. Journal of Maps, 7(1): 507-518.

TVerijonaite, E., ÓlafsdótTir, R. and ThORSTEInsson, T. (2018): Accessibility of protected areas and visitor behaviour: A case study from Iceland. Journal of Outdoor Recreation and Toursim, 24: 1-10.

VIKEN, A. (2011): Tourism, research, and governance on Svalbard: a symbiotic relationship. Polar Record, 47: 335-347.

WANG, S., ZHou, L. (2019): Integrated impacts of climate change on glacier tourism. Advances in Climate Change Research, 10: 71-79.

WANG, S., Du, J., LI, S., HE, H. and Xu, W. (2019): Impact of tourism activities on glacial changes based on the tourismheat footprint (THF) method. Journal of Cleaner Production, 215: 845-853.

\section{Web sources / Other sources}

[1] SSB (2019): Statistics Norway - StatBank Norway database; https://www.ssb.no/en/statbank/ accessed on September $19^{\text {th }} 2019$.

[2] Loftmyndir (2019); accessed September $19^{\text {th }} 2019$; http://www.map.is

[3] National Land Survey of Iceland database (2019); https://www.lmi.is/en/aerial-photos/ 